$\xi=-1$

\title{
Multi Crop Optimization Using Linear Programming Model for Maximum Net Benefit
}

\author{
Shreedhar R \\ "Professor, Department of Civil Engineering, \\ ,KLS Gogte Institute of Technology, Belagavi, Karnataka State, India” \\ *Corresponding Author Email: rshreedhar@git.edu
}

\begin{abstract}
The water used for agriculture is $70 \%$ globally. This has resulted in new methods of saving water. Hence water saving techniques has to be practiced. In water resources planning and management, optimization techniques is used for limited use of resources such as such as water, land, production cost, manpower, fertilizers, seeds, and pesticides. For cultivating each crop, the land area needs to be planned properly. Hence the crop pattern has to be decided optimally depending on available water resources and on economic basis. Therefore farmer needs to be educated to adopt optimum cropping pattern which maximises the economic returns. Hence the study is taken up to optimize the allocation of land areas to crops. The objective function for multi crop model were formulated using linear programming for maximizing the net benefits. The study resulted in optimal cropping pattern for different water availabilities ranging from $2000 \mathrm{Ha}-\mathrm{m}$ to 5500 Ha-m. The maximum net benefit for the study area varied from Rs. 53.2 Crores for 2000 Ha-m water availability to Rs. 78 Crores at 5000 Ha-m water availability.
\end{abstract}

Key Words: Optimization techniques, LP, crop pattern, maximum net Benefits, water availability.

\section{Introduction}

The greater efficiency in water usage is required in rainfed and in irrigated agriculture due to shortage of water resources and increased food requirements. Hence the water usage has to be reduced by proper planning without sacrificing the yield. CROPWAT model can be used to develop practical solutions and recommend crop pattern by optimizing scarce water resources CROPWAT [1] is a practical tool which helps in planning to manage scarce water resources. The engineers have to carry out standard calculations for evapotranspiration and crop water usage. Hence recommendations can be made with respect to improved practices in irrigation and better planning of irrigation schedules. Ali Abdzad Gohari adopted the CROPWAT model to appropriately estimate the yield reduction caused by water stress and climatic impacts. The simulation results analysis suggest that in both condition rainfed and irrigated, the largest yield reduction occurred in the stage three(developmental stage) [2]. A study was carried out by Nithya et al to determine the crop water requirement of some selected crops such as groundnut, rice, pulses, sugarcane and millet(ragi). Crop water requirement for each of the crops was determined using 30-year climatic data in CROPWAT. Reference crop evapotranspiration (ETo) was determined using the FAO Penman Monteith method. [3] Shreedhar et.al carried out study to review the crop yield responses to deficit irrigation for the major crops in Kunigal command area [4].

To plan the with regard to distribution of water resources to the crop, it is important to optimize the available land and water resources to achieve maximum returns. To solve such problems, the mathematical programming models like linear programming
(LP), dynamic programming (DP) and genetic algorithm (GP) are used. Linear programming is the most convenient and effective tool to handle more number of constraints. Hall and Dracup (1970) used LP model to maximize the net benefit and select an optimal cropping pattern [5]. Loucks et al.(1981) discussed in detail about the micro level irrigation planning with detailed examples [6]. Singh et al. (2001) applied linear programming model to Shahi distributory command area to obtain net returns at different water availability levels [7]. Srinivasa Raju et al. (2000) used linear programming models to obtain various possible optimal cropping patterns and optimal operational policies considering different dependability inflow levels [8]. A study is carried out to determine the crop water requirement of some selected crops for the command area in Markandeya command area. These crops include jowar, Groundnut, Hybrid Maize, Pulses, Mexican Wheat, Bengal Gram, Green Gram and Sunflower [9].

\section{Study Area}

The area taken for the study is Markandeya Reservoir Project as shown in Figure 1.0. The river Markandeya is a major tributary to Ghataprabha River which is a tributary to river Krishna. It takes its origin near Bailur in the Western Ghats and flows for a length of $66 \mathrm{kms}$ before it joins river Ghataprabha near Gokak. The Markandeya River flows entirely in Belgaum district of Karnataka state with a drainage basin of 432 Sqkms. The project envisages the construction of concrete dam across Markandeya River near Shirur village in Belgaum district to irrigate lands on both banks to an extent of 14850 Hectares of Belgaum, Hukkeri, Gokak, and Saundatti Talukas. The proposed dam site across Markandeya river is located at latitude $16^{\circ} 2^{\prime} 0^{\prime \prime} \mathrm{N}$ and longitude $74^{\circ} 38^{\prime} 30^{\prime \prime} \mathrm{E}$ 
and near Shirur village which is about $10 \mathrm{kms}$ from Pachapur railway station on Miraj-Bangalore section of the South Central Railway.'

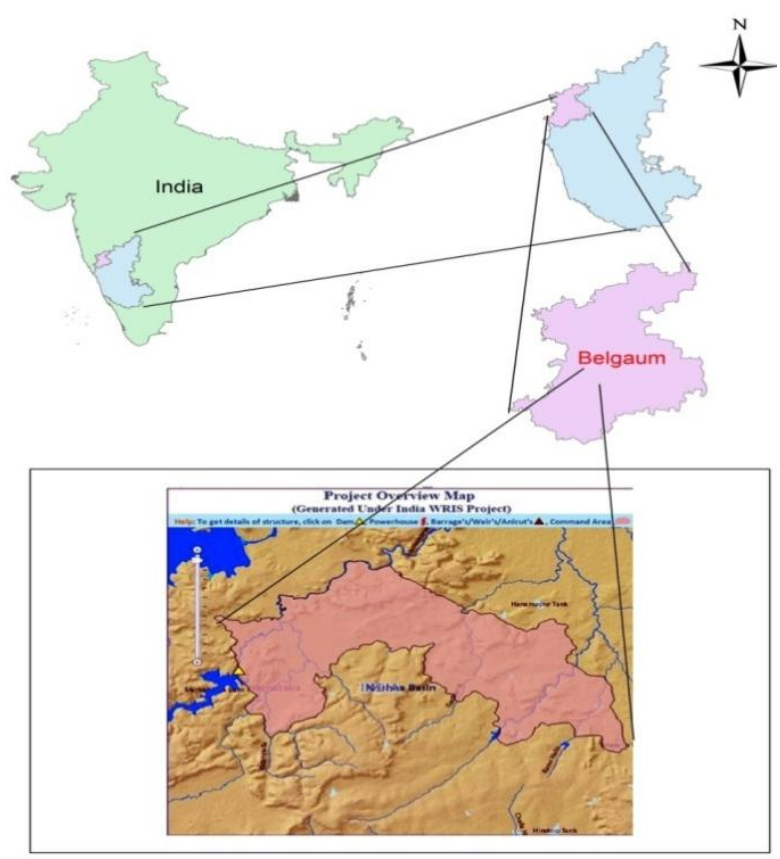

Fig. 1: Location Map of Markandeya Study area

\section{LP Model Formulation}

The different proposed cropping pattern scenario is formulated for Markandeya command area based on irrigable command area and volume of water at different water availability in the reservoir. The irrigation water requirements of major crops in the study area are estimated. A LP model is used to get the cropping pattern optimally so as to obtain maximum net benefit at different water availability in the reservoir. The objective function of the model is subject to the following constraints: water availability, crop land requirement, Human labour cost, Animal and Machine power cost, Seed cost, Fertlizers and Manure cost, Fixed cost etc.

\subsubsection{Objective function: Maximize Net Benefit}

$$
Z=\sum\left(\mathrm{Y}_{\mathrm{i}} \times \mathrm{A}_{\mathrm{i}}\left(\mathrm{R}_{\mathrm{i}}-\mathrm{C}_{\mathrm{i}}\right)\right.
$$

where,

$Y i=Y$ ield of ' $i$ 'th crop in study area in Quintal, $A i=$ Area of ' $i$ 'th crop in study area in Hectare, $\mathrm{Ri}=$ Market price of ' $\mathrm{i}$ 'th crop in $\mathrm{Rs} / \mathrm{Qtl}$ and $\mathrm{Ci}=$ Cost of cultivation in Rs/Qtl “

The above objective function is subjected to the following requirements

\subsubsection{Constraints on Water Availability}

$$
\sum \mathrm{NIR}_{\mathrm{i}} \times \mathbf{A}_{\mathrm{i}} \leq \mathrm{WA}
$$

where, $\mathrm{NIR}_{\mathrm{i}}=\mathrm{Net}$ Irrigation Requirement for the $\mathrm{i}^{\text {th }}$ crop ,WA=Water Availability in Ha-m and $A_{i}=$ Area of $i^{\text {th }}$ crop in study area

\subsubsection{Constraints on Crop land Requirement}

$$
\sum \mathrm{A}_{\mathrm{i}} \leq \mathrm{CCA}
$$

where, $A_{i}=$ Area of $i^{\text {th }}$ crop in Study area in $\mathrm{Ha}$ and $\mathrm{CCA}=$ Cultivable Command Area in Ha.

\subsubsection{Constraints on Human labour Cost}

$$
\sum \mathrm{CHL}_{\mathrm{i}} \times \mathrm{A}_{\mathrm{i}} \leq \mathrm{CHL}
$$

where, $\mathrm{CHL}_{\mathrm{i}}=$ Cost of Human Labour Per Ha in Rs, $\mathrm{A}_{\mathrm{i}}=$ Area of $\mathrm{i}^{\text {th }}$ crop in Study area in $\mathrm{Ha}$ and $\mathrm{CHL}=$ Total cost of Human labour for entire CCA in Rs.

\subsubsection{Constraints on Animal and Machine Power Cost}

$$
\sum \mathrm{CAMP}_{\mathrm{i}} \times \mathrm{A}_{\mathrm{i}} \leq \mathrm{CAMP}
$$

where, $\mathrm{CHL}_{\mathrm{i}}=$ Cost of $\mathrm{i}^{\text {th }}$ crop human labour charges Per Ha in Rs. $\mathrm{A}_{\mathrm{i}}=$ Area of $\mathrm{i}^{\text {th }}$ crop in Study area in $\mathrm{Ha}$ and $\mathrm{CHL}=$ Total cost of Human labour for entire CCA in Rs.

\subsubsection{Constraints on Seed Cost}

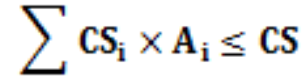

Where, $\mathrm{CS}_{\mathrm{i}}=$ Cost of $\mathrm{i}^{\text {th }}$ crop seed per Ha in Rs., $\mathrm{A}_{\mathrm{i}}=$ Area of $\mathrm{i}^{\text {th }}$ crop in Study area in Ha. AndCS= Total cost of seeds per entire CCA inRs.

\subsubsection{Constraints on Fertilizer and Manure Cost}

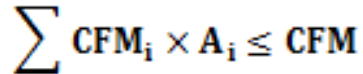

Where, $\mathrm{CFM}_{\mathrm{i}}=$ Cost of $\mathrm{i}^{\text {th }}$ crop Fertilizers and Manure per Ha in Rs., $A_{i}=$ Area of $i^{\text {th }}$ crop in Study area in Ha.and CFM= Total cost of Fertilizers and Manure per entire CCA in Rs.

\subsubsection{Constraints on Interest on Workmanship Cost}

$$
\sum \mathrm{CIW}_{\mathrm{i}} \times \mathrm{A}_{\mathrm{i}} \leq \mathrm{CIW}
$$

Where, $\mathrm{CIW}_{\mathrm{i}}=$ Cost of $\mathrm{i}^{\text {th }}$ crop interest on workmanship per Ha in Rs, $A_{i}=$ Area of $i^{\text {th }}$ crop in Study area in Ha.and CIW= Total cost of Interest on Workmanship per entire CCA in Rs.

\subsubsection{Constraints on Plant Protection Cost}

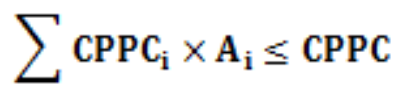

Where, $\mathrm{CPPC}_{\mathrm{i}}=$ Cost of $\mathrm{i}^{\text {th }}$ crop plant protection charges per Ha in Rs, $A_{i}=$ Area of $i^{\text {th }}$ crop in study area in $\mathrm{Ha}$ and $\mathrm{CPPC}=$ Total cost of plant protection charges per entire CCA in Rs.

\subsubsection{Constraints on Fixed Cost}

$$
\sum \mathrm{CFC}_{\mathrm{i}} \times \mathrm{A}_{\mathrm{i}} \leq \mathrm{CFC}
$$

Where, $\mathrm{CFC}_{\mathrm{i}}=$ Cost of $\mathrm{i}^{\text {th }}$ crop fixed cost (land revenue, surface water charges) per $\mathrm{Ha}$ in Rs. , $\mathrm{A}_{\mathrm{i}}=$ Area of $\mathrm{i}^{\text {th }}$ crop in study area in Ha. and CFC $=$ Total amount of fixed cost per entire CCA in Rs. 


\subsubsection{Constraints on Unforeseen Expenditure}

$$
\sum \operatorname{CUFE}_{\mathrm{i}} \times \mathrm{A}_{\mathrm{i}} \leq \mathrm{CUFE}
$$

Where, $\mathrm{CUFE}_{\mathrm{i}}=$ Cost of $\mathrm{i}^{\text {th }}$ crop unforeseen expenditure per Ha in Rs. $A_{i}=$ Area of $i^{\text {th }}$ crop in study area in Ha.and CUFE $=$ Total amount of unforeseen expenditure per entire CCA in Rs.

\section{Results and Discussions}

The linear programming model is run for lowest water availability of 2000 Ha-m and then the model is also run for increased water availability in the increments of $1000 \mathrm{Ha}-\mathrm{m}$. For each run, the optimal area of each crop to be allotted shall be less than or equal to total area of land allotted to each of the crops as given by the Irrigation department. The decision variables ineach case are the optimal area of land allotted to each of the crops such that maximum net benefit is obtained. However, the study was also carried for each of the water availability case by varying the allotted areas for each crop by $\pm 10 \%$ to $\pm 50 \%$.

The maximum cultivable areas and maximum net benefit obtained for each run in LP model for various water availability in the reservoir is as given in Figures 2. To 9.

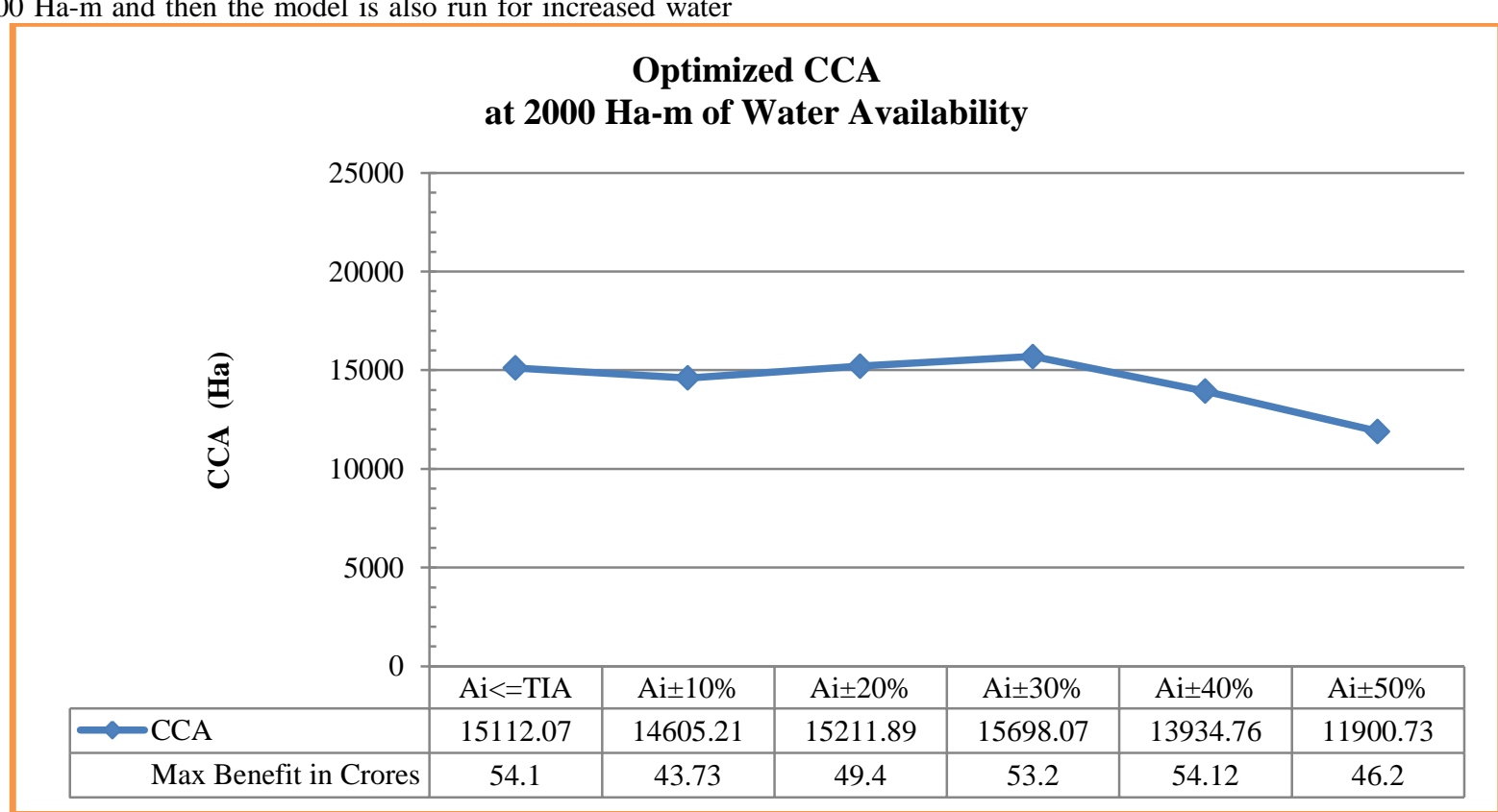

Fig.2: Optimal Crop area for water availability of $2000 \mathrm{Ha}-\mathrm{m}$

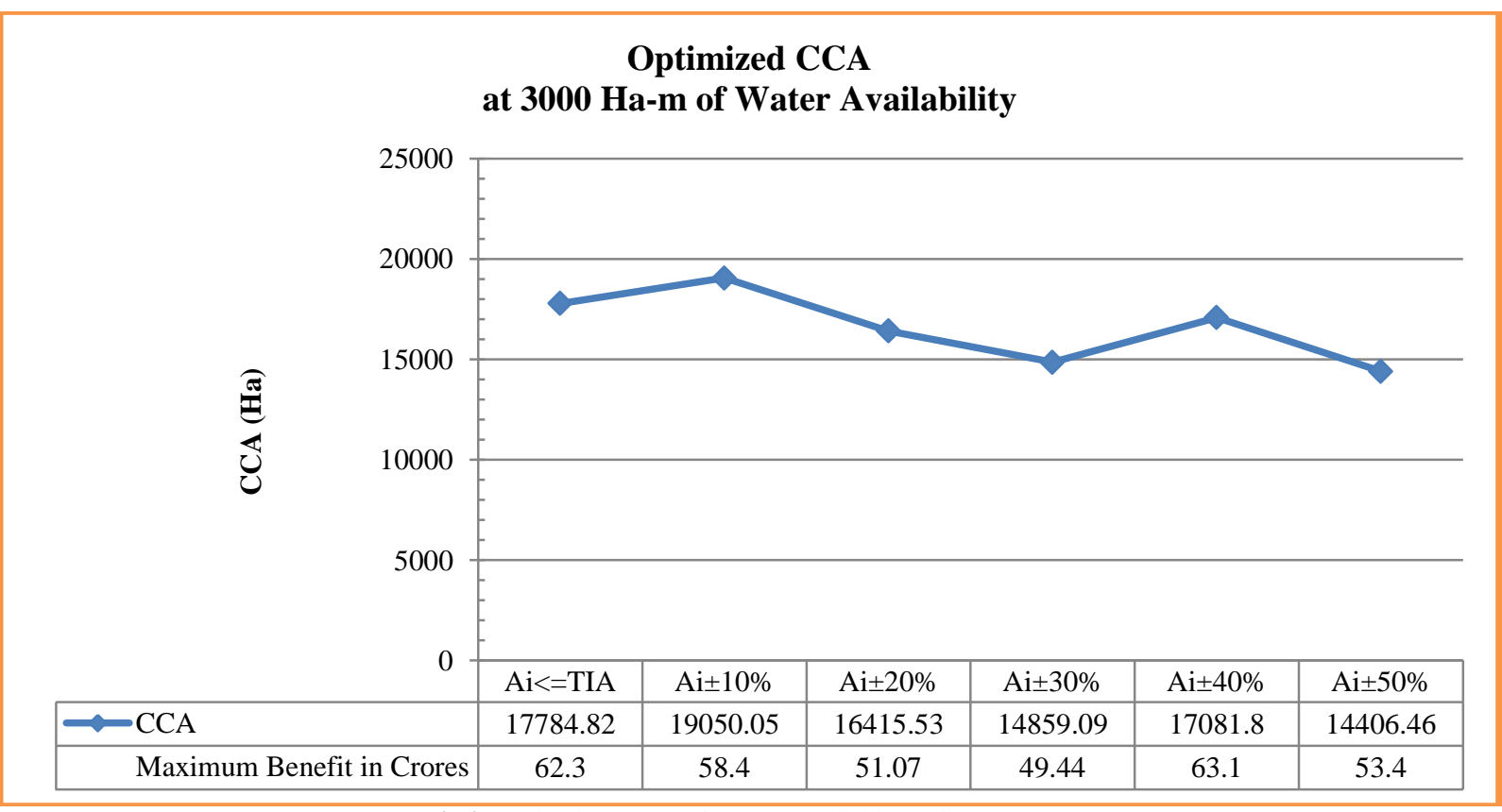

Fig.3: Optimal Crop area for water availability of $3000 \mathrm{Ha}-\mathrm{m}$ 


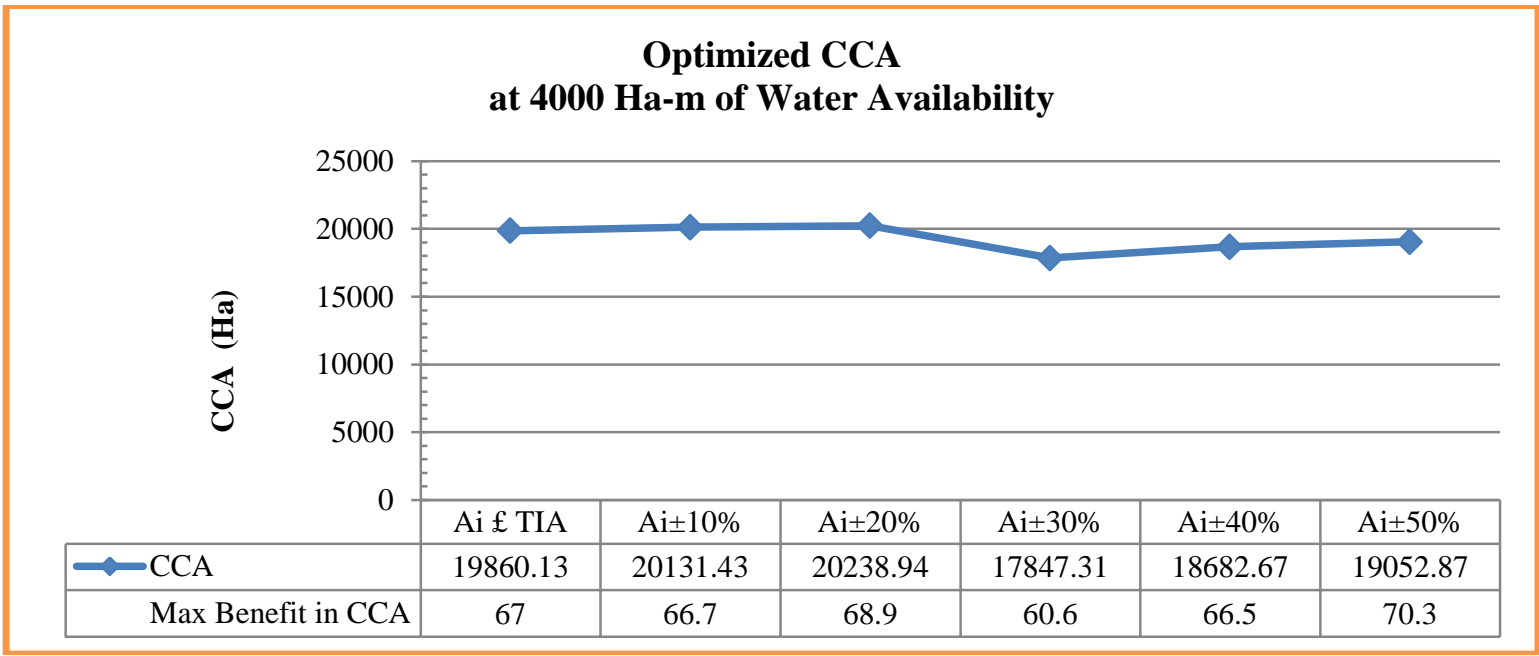

Fig. 4: Optimal Crop area for water availability of $4000 \mathrm{Ha}-\mathrm{m}$

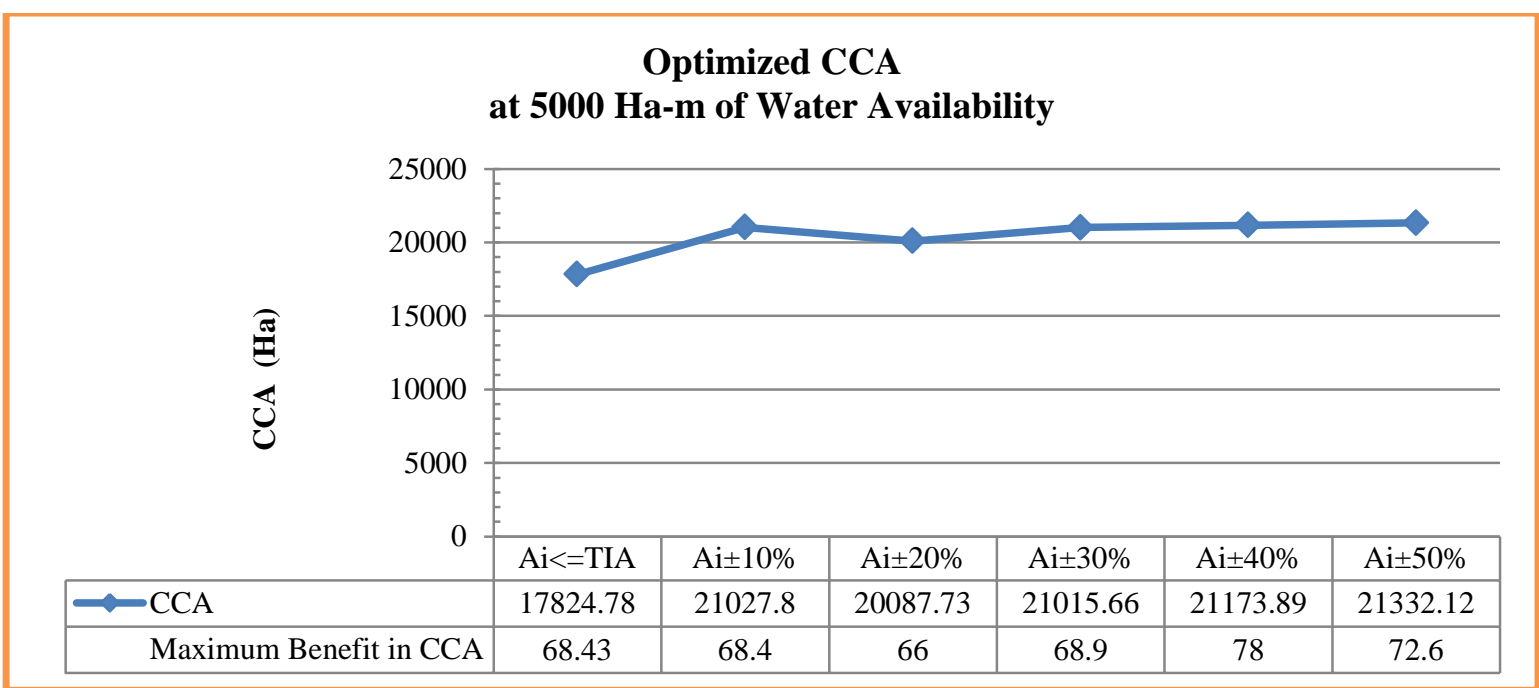

Fig. 5: Optimal Crop area for water availability of $5000 \mathrm{Ha}-\mathrm{m}$

Table 1."Optimized cropping pattern in study area for different water availabilities"

\begin{tabular}{|c|c|c|c|c|c|c|}
\hline \multirow[b]{2}{*}{ Season } & \multirow[b]{2}{*}{ CROPS } & \multirow[b]{2}{*}{$\begin{array}{l}\text { EXISTING } \\
\text { AREA in Ha }\end{array}$} & \multicolumn{4}{|c|}{ WATER AVAILABILITY } \\
\hline & & & $\begin{array}{c}2000 \text { Ha-m at } \\
\pm 30 \% \mathrm{Ai}\end{array}$ & $\begin{array}{c}3000 \text { Ha-m at } \\
\pm 40 \% \mathrm{Ai}\end{array}$ & $4000 \mathrm{Ha}-\mathrm{m}$ at $\pm 20 \% \mathrm{Ai}$ & $\begin{array}{c}5000 \text { Ha-m at } \\
\pm 40 \% \mathrm{Ai}\end{array}$ \\
\hline \multirow{3}{*}{ 言 } & JOWAR & 2435 & 1823.07 & 1850 & 2940 & 3430 \\
\hline & MAIZE & 3570 & 4641 & 3487.14 & 4284 & 3988.64 \\
\hline & PULSES & 3435 & 2404.5 & 2061 & 2748 & 2061 \\
\hline \multirow{7}{*}{$\sum^{\infty}$} & JOWAR & 1465 & 1025.5 & 879 & 1248.69 & 2051 \\
\hline & MAIZE & 1955 & 0 & 1173 & 1564 & 1173 \\
\hline & WHEAT & 3380 & 0 & 0 & 0 & 2028 \\
\hline & BENGAL GRAM & 515 & 360.5 & 309 & 412 & 309 \\
\hline & GREEN GRAM & 515 & 360.5 & 309 & 412 & 309 \\
\hline & SUNFLOWER & 1080 & 0 & 648 & 1296 & 1512 \\
\hline & COTTON & 1485 & 0 & 891 & 1188 & 1300.8 \\
\hline \multicolumn{3}{|c|}{$\mathrm{CCA}$ in $\mathrm{Ha}$} & 15698.07 & 17081.8 & 20238.94 & 21173.89 \\
\hline \multicolumn{3}{|c|}{ Maximum Benefit in Crores } & 53.2 & 63.1 & 68.9 & 78 \\
\hline
\end{tabular}

The maximum cultivable crop area allotted by LP model with constraint $\mathrm{Ai}<=$ TIA is $15112.07 \mathrm{Ha}$ for a water availability of 2000 Ha-m with net benefit of Rs. 54.1 Crores. But no area is allotted for the crops such as Rabi Jowar, Rabi Wheat, Rabi Bengal Gram, Rabi Green Gram and Seasonal Cotton. As the restriction on crop areas was relaxed by $\pm 10 \%$ to $\pm 50 \%$, maximum area gets allotted to Kharif Groundnut thus giving also the maximum net benefit of Rs. 53.2 Crores.

The maximum cultivable crop area allotted by LP model with constraint $\mathrm{Ai}<=$ TIA for water availability of $3000 \mathrm{Ha}-\mathrm{m}$ is 17784.82 Ha with net benefit of Rs. 62.3 Crores. The maximum net benefit at $40 \%$ variation is Rs. 63.1 Crores even though the total cultivable crop area is less than first run of LP model.
Though at $50 \%$ variation, the LP model allots the optimal areas for all crops, the net benefit is less than $40 \%$ variation.

The maximum cultivable crop area allotted by LP model with constraint $\mathrm{Ai}<=$ TIA for water availability of $4000 \mathrm{Ha}-\mathrm{m}$ is 19860.13 Ha with net benefit of Rs. 67.0 Crores. But no area is allotted for the crops such as Rabi Bengal Gram and Rabi Green Gram. As the restriction on crop areas was relaxed by $\pm 10 \%$ to $\pm 50 \%$, maximum area gets allotted to Kharif Groundnut. The maximum net benefit at $50 \%$ variation is Rs. 70.3 Crores even though the total cultivable crop area is less than first run of LP model. Though at 30 and $40 \%$ variation, the LP model allots the optimal areas for all crops, the net benefit is less than $50 \%$ variation. Also the total cultivable area at $10 \%$ and $20 \%$ variation 
is more than first run and $50 \%$ variation, the net benefit is less than 70.3 Crores.

The maximum cultivable crop area allotted by LP model with constraint Ai<=TIA for water availability of $5000 \mathrm{Ha}-\mathrm{m}$ is $17824.78 \mathrm{Ha}$. As the restriction on crop areas was relaxed by $\pm 10 \%$ to $\pm 50 \%$, maximum area gets allotted to Kharif Maize. The maximum net benefit at $40 \%$ variation is Rs. 78.0 Crores though the total cultivable crop area is less than $50 \%$ variation. Though at $20 \%, 30 \%$ and $50 \%$ variation, the LP model allots the optimal areas for all crops, the net benefit is less than $40 \%$ variation.

Thus the optimal cropping pattern for Markandeya command area for various water availability with restriction on crop areas being relaxed so as to give maximum net benefit is as given in Table 1 .

\section{Conclusions}

Markandeya reservoir project was designed to irrigate $23760 \mathrm{Ha}$ of land. The maximum capacity of reservoir is $9344 \mathrm{Ha}-\mathrm{m}$. The different proposed cropping pattern scenario is formulated for Markandeya command area based on irrigable command area and volume of water at different water availability in the reservoir Based on the study carried out, the following conclusions are made:

i. The mean monthly rainfall data for about past 30 years and Hydro-Meteorolological data for past 10 years are used for calculating the net irrigation requirements for each of the crops in the study area.

ii. LINGO software is used to get the maximum net benefit for the study area.

iii. The objective function of the model is subject to the following constraints: water availability, crop land requirement, Human labour cost, animal and machine power cost, seed cost, fertlizers and manure cost, fixed cost etc.

iv. The linear programming model is run for lowest water availability of $2000 \mathrm{Ha}-\mathrm{m}$ and then the model is also run for increased water availability in the increments of $1000 \mathrm{Ha}-\mathrm{m}$.

v. The optimal area of each crop to be allotted by LP model is less than or equal to total area of land allotted to each of the crops as given by the Irrigation department thus meeting the objective of maximum net benefit.

vi. The study is also carried for each of the water availability case by varying the allotted areas of each crop by \pm 10 $\%$ to $\pm 50 \%$.

vii. The maximum net benefit for $2000 \mathrm{Ha}-\mathrm{m}$ availability is 54.12 Crores and increases to 78 Crores for 5000 Ha-m water availability.

viii. The total optimal cultivated area by LP model for 2000 Ha-m water availability is found to be 15485.62 Hectares and is increased to 21173.82 Hectares for $5000 \mathrm{Ha}-\mathrm{m}$ water availability.

ix. This different optimum cropping areas and net benefit obtained from LP model for different water availabilities are summarized in Table 1.

\section{Acknowledgements}

The author's wishes to thank the Management and Principal of KLS Gogte Institute of Technology, Belagavi, Karnataka, India for their continued support in carrying out this research work.

\section{References}

[1] M. Smith,Food and Agriculture Organization (FAO) (1992) CROPWAT: A Computer Program for Irrigation Planning and Management,. FAO Irrigation and Drainage Paper No. 46. Rome.”

[2] Ali Abdzad Gohari, "Simulation of Peanut (Arachis hypogaea L.) with Cropwat model in Irrigation Condition and Rainfed". Sci. Agri.2 (3), 2013, 54-59."
[3] Nithya B.K., Shreedhar .R., Dr. Shivapur A.V., "Water Requirements of Selected Crops in Kunigal Command Area", Imanager's Journal of Civil Engineering" - (eISSN 2249-0779, pISSN 2231-1068), Volume 5, Issue 2, March-May 2015, pp 24 30."

[4] Shreedhar .R., Dr. Shivapur A.V., Nithya B.K., "Deficit Irrigation management of Major Crops in Kunigal Command Area", International Journal of Scientific \& Engineering Research, Volume 6, Issue 9, September-2015, ISSN 2229-5518, pp 170-185. “

[5] "Hall, W. A., and Dracup, J. A.Water Resources System Engineering, McGrawHill, New york,1970."

[6] Loucks, D. P., Stedinger, J. R. and Haith, D. A, “ Water Resources System Planning and Analysis" Prentice Hall, Englewood Cliffs, New Jersey, 1981."

[7] Singh, D. K., Jaiswal, C. S., Reddy, K. S., Singh, R. M., and Bhandarkar, D. M., "Optimal Cropping Pattern in a Canal Command Area", Agricultural Management, pp 1-8, 2001"

[8] Srinivasa Raju, K., and Nagesh Kumar, D., "Optimum cropping pattern for Sri Ram Sagar Project: A Linear Programming approach", Journal of Applied Hydrology, Volume 13, No.1 \& 2 , page 56-67, 2000. 